\title{
Public school teachers' satisfaction with retention factors in relation to work engagement
}

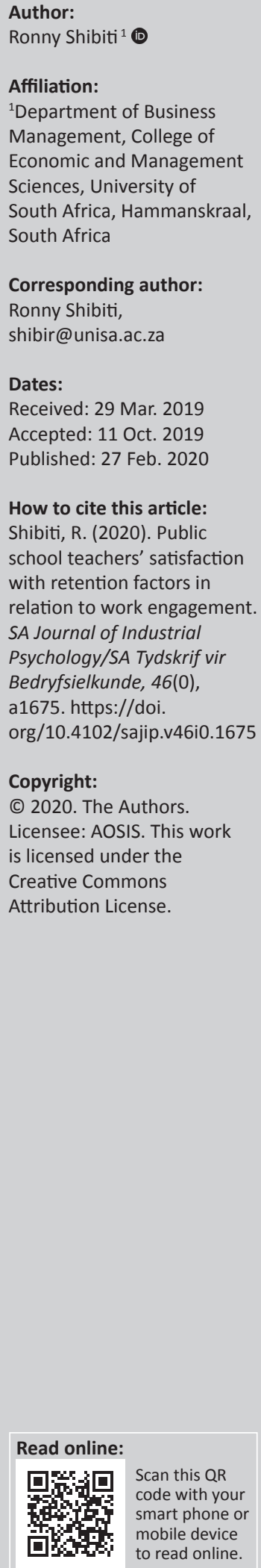

Orientation: The quality of education is influenced by the engagement, well-being, retention and performance of teachers. Literature shows that teachers are exiting the teaching profession at an alarming rate, and there are various and intertwined reasons compelling teachers to leave their jobs.

Research purposes: The purpose of this study was to investigate the influence of retention factors on work engagement.

Motivation for the study: Turnover among teachers is high, and many teachers are leaving the profession during their early years of teaching. An empirical investigation of the relationship between retention factors and work engagement and the results of utilising retention factors and work engagement to facilitate employee retention is needed.

Research approach/design and method:A quantitative design was used, and 278 questionnaires were collected from a convenience sample of teachers from public schools in the Tshwane Municipality.

Main findings: Correlational analysis revealed significant relationships between retention factors and work engagement. Multiple regression analyses revealed that retention factors significantly predict work engagement. The main practical contribution of this study is the way in which it has demonstrated that retention factors relate to and predict work engagement.

Practical/managerial implications: Organisations should provide their employees with improved compensation, training and development, and career opportunities as this may improve employees' work engagement. Therefore, organisations should determine whether employees are satisfied with these retention factors as provided in the organisation.

Contribution/value-add: This study adds to the psychological attachment theory by suggesting that employees satisfied with retention factors in their organisations are more likely to be engaged.

Keywords: retention factors; work engagement; compensation; work-life balance; career development; training and development; vigour; dedication; absorption.

\section{Introduction}

Quality education highly depends on the engagement, well-being, retention and performance of teachers (Fouché, Rothmann, \& Van der Vyver, 2017). In 2013, research studies highlighted that the basic education system needs about 25 000-30 000 teachers every year. However, the tertiary system supplies between 6000 and 8000 teachers a year, with about 10000 in an exceptional year (Miya, 2017). Furthermore, the worrying reality in the literature is that teachers are exiting the teaching profession at an alarming rate (Centre for Development and Enterprise, 2015; Hugo, 2018; Mafukata \& Mudau, 2016; Mampane, 2012). According to Mafukata and Mudau (2016), there is a high turnover among teachers, with many teachers leaving the industry in their early years of teaching. A high number of competent, graduate teachers choose to relocate to other countries or find employment in other industries. As a result, thousands of teachers are lost on an annual basis (Centre for Development and Enterprise, 2015). More than a quarter of recently qualified teachers are dissatisfied with the teaching profession in South Africa because of low salaries and the poor image associated with teaching profession (Centre for Development and Enterprise, 2015). Moreover, high numbers of teachers who leave the industry are not replaced because of the inefficiency of the tertiary system to address the training and developmental needs of teachers in South Africa (Hugo, 2018; Mafukata \& Mudau, 2016). This is contrary to the Department of Basic Education's stance that the number of newly qualified teachers has recently tripled and more teachers remain in the public education system (Citizen, 2018). Furthermore, recent statistics regarding teachers' turnover rate does not 
support the narrative that the turnover rate of teachers in South Africa is very high. However, the study is warranted because the challenge is generally emphasised in the literature.

According to Furuta (2015), teachers are motivated to remain with their current school if their contributions are acknowledged, and if they feel that they have made a positive contribution to the social circumstance of the school, such as having a good relationship with learners, colleagues and administrators. Nevertheless, the reasons for encouraging teachers to vacate their positions are many and interlinked (Mafukata \& Mudau, 2016). Teachers with certain characteristics may be more likely to leave, compared to other teachers (Pitsoe, 2013). Therefore, it is critical to implement measures that will improve the retention of teachers with highly needed competencies in order to meet the demand in public schools. A profound understanding of the factors that may improve teacher retention in public schools is needed, and of the way in which variables such as retention factors and work engagement impact on the retention of employees. According to Schaufeli and Bakker (2004), work engagement is imperative because, in general, engaged employees are very fond of the organisation they work for and are more likely to remain indefinitely.

The purpose of this study was to investigate the influence of retention factors on work engagement of public schools teachers in the Tshwane Municipality, South Africa. A nonexperimental, quantitative study was conducted using a survey. Convenience sampling technique was used, and questionnaires (hard copies) were distributed to teachers in Tshwane Municipality public schools. This study adopted Döckel's (2003) retention factors and Schaufeli, Salanova, Gonzalez-Roma and Bakker's (2002) work engagement models to address the problem of teacher retention.

\section{Research purpose and objectives}

The purpose of this study was to investigate the influence of retention factors on work engagement of teachers in Tshwane Municipality public schools. To this effect, the following objectives were formulated:

Research objective 1: To establish the relationship between retention factors and work engagement.

Research objective 2: To determine whether retention factors positively and significantly predict work engagement.

Research objective 3: To determine whether retention factors positively and significantly predict the three sub-factors of work engagement, namely, vigour, dedication and absorption.

\section{Literature review}

\section{Retention factors}

Employee retention can be defined as the interventions implemented by an organisation to build an atmosphere that will encourage employees to stay for a longer period and thereby discourage qualified and experienced employees from exiting the organisation (Mohammad, 2015; Sandhya \&
Kumar, 2014). When employees leave an organisation, it may be detrimental for the organisation's performance and success (Mohammad, 2015; Sandhya \& Kumar, 2014). Hence, it is critical that organisations motivate employees to remain by endorsing policies and practices that satisfy employees' various needs (Mahalakshmi \& Rao, 2012). Retention factors can be defined as the human resource (HR) practices that organisations introduce to attract and motivate employees to stay with the organisation (Coetzee, Oosthuizen, \& Stoltz 2016; Kumar \& Santhosh, 2014, Shibiti, 2017). Retention factors enhance employees' performance (Coetzee et al., 2016; Kumar \& Santhosh, 2014; Van Dyk, Coetzee, \& Takawira, 2013) and influence employees' turnover intentions. Hence, such factors should be considered while formulating retention strategies (Dhanpat, Modau, Lugisani, Mabojane, \& Phiri, 2018; Van Dyk et al., 2013). Management is responsible for identifying and implementing $\mathrm{HR}$ interventions, which should discourage employees from leaving the organisation (Tourangeau, Patterson, Saari, Thomson, \& Cranley, 2017). A lack of these HR interventions in an organisation may lead to employee turnover (Coetzee \& Pauw, 2013; Cohen, Cavazotte, Da Costa, \& Ferreira, 2017; Tourangeau et al., 2017). Table 1 highlights retention factors identified by different researchers.

This study adopted the six retention factors identified by Döckel (2003). These retention factors are described as follows:

1. Compensation relates to the desirability of the salary package, organisational remuneration policies and the value of benefits.

2. Job characteristics relate to the features of the job, for example, diverse work, prospects for resolving complex problems, working with talented employees, flexibility, freedom and opportunities to work on challenging projects.

TABLE 1: Factors that enhance employee retention in organisations.

\begin{tabular}{|c|c|}
\hline Author & Retention factors \\
\hline Döckel (2003) & $\begin{array}{l}\text { Compensation, job characteristics, training and } \\
\text { development opportunities, supervisor support, } \\
\text { career opportunities and work or life balance }\end{array}$ \\
\hline $\begin{array}{l}\text { Coetzee and Stoltz (2015); } \\
\text { Davidescu and Issa Eid (2017); } \\
\text { Kumar and Santhosh (2014); Lyria, } \\
\text { Namusonge and Karanja (2017) }\end{array}$ & $\begin{array}{l}\text { Work-life balance, compensation, opportunities } \\
\text { for career growth and development, the } \\
\text { opportunity to use one's skills and knowledge in } \\
\text { the company, and challenging work }\end{array}$ \\
\hline Mohammad (2015) & $\begin{array}{l}\text { Employee involvement, provision of trust-based } \\
\text { inspirational leadership, fair compensation, } \\
\text { orientation, health and safety programmes, } \\
\text { training programmes, fair rewards or incentives, } \\
\text { developing grievance-handling mechanisms, } \\
\text { flexibility in working hours, coaching, mentoring } \\
\text { and maintaining positive relationships between } \\
\text { employees }\end{array}$ \\
\hline Roy (2015) & $\begin{array}{l}\text { Offering employees an optimal working } \\
\text { environment, career growth opportunities, } \\
\text { rewards, work-life balance and supervisor } \\
\text { support that is inspirational }\end{array}$ \\
\hline Pek-Greer and Wallace (2017) & $\begin{array}{l}\text { Employee benefits, employee remuneration, } \\
\text { professional development opportunities and } \\
\text { work environment }\end{array}$ \\
\hline $\begin{array}{l}\text { Coetzee and Pauw (2013); } \\
\text { Tourangeau et al. (2017) }\end{array}$ & $\begin{array}{l}\text { A safe and non-toxic work environment, a } \\
\text { conducive work relationship between managers } \\
\text { and subordinates, and rewards to employees for } \\
\text { good performance }\end{array}$ \\
\hline
\end{tabular}

Note: Please see the full reference list of the article, Shibiti, R. (2020). Public school teachers' satisfaction with retention factors in relation to work engagement. SA Journal of Industrial
Psychology/SA Tydskrif vir Bedryfsielkunde, 46(0), a1675. https://doi.org/10.4102/sajip. v46i0.1675, for more information. 
3. Training and development opportunities relate to training that is job-specific, prospects for personal growth and development, and transfer of learning in the work environment.

4. Supervisor support relates to the feedback that supervisors provide to their subordinates with regard to their personal performance, praise and appreciation, reward and acknowledgement of outstanding performance.

5. Career opportunities relate to advancement and individual career development opportunities within the organisation.

6. Work-life balance can be defined as one's opportunity to balance work and life commitments.

The retention factors identified by Döckel (2003) are essential to employee retention in the South African environment (Dhanpat et al., 2018; Döckel, 2003; Van Dyk \& Coetzee, 2012). Implementation and practices of the interventions should inspire employees to give their best and discourage them from leaving the organisation. The next section discusses work engagement and the way in which work engagement improves employee retention.

\section{Work engagement}

Work engagement evolved from Kahn's (1990) personal engagement theory and has been a leading research focus area in the field of organisational behaviour, and it owes its origin to its relationship with different positive organisational outcomes (Nishi, Suzuki, Nishida, Mishima, \& Yamanouchi, 2017; Presbitero, 2017; Wang, Liu, Zou, Hao, $\& \mathrm{Wu}, 2017)$. The variable is defined diversely because of the varying perspectives held by consultants, academic scholars and practitioners, with the definitions differing in depth and scope (Bailey, Madden, Alfes, \& Fletcher, 2017). For the purpose of this study, work engagement encompasses a positive, fulfilling, work-related state of mind that is characterised by vigour, dedication and absorption (Du Plessis \& Boshoff, 2018; Kallioniemi, Kaseva, Kolstrup, Simola, \& Kymäläinen, 2018; Kulikowski, 2019; Mitonga-Monga \& Hlongwane, 2017; Reitz, 2014; Schaufeli \& Bakker 2004; Schaufeli et al., 2002; Van Dyk et al., 2013).

Vigour can be defined as high levels of energy and mental resilience while working, the willingness to invest effort in one's work and persistence even in the face of adversities (Du Plessis \& Boshoff, 2018; Kallioniemi et al., 2018; Malik, Shahzad, \& Raziq, 2019; Mitonga-Monga \& Hlongwane, 2017; Schaufeli \& Bakker 2004; Schaufeli et al., 2002). Dedication can be defined as being involved in one's work and experiencing a sense of significance, enthusiasm and challenge (Du Plessis \& Boshoff, 2018; Kallioniemi et al., 2018; Malik et al., 2019; Mitonga-Monga \& Hlongwane, 2017; Schaufeli \& Bakker, 2004; Schaufeli et al., 2002; Van Dyk et al., 2013). Absorption can be defined as being fully concentrated and happily immersed in one's work whereby time passes quickly (Du Plessis \& Boshoff, 2018; Malik et al., 2019; Schaufeli \& Bakker, 2004; Schaufeli et al., 2002).
Effective human resource management (HRM) practices can influence levels of work engagement and improve the client's service quality, satisfaction and retention; offer a distinctive competitive advantage; and improve the performance of the organisation (Burke, Koyuncu, Fiksenbaum, \& Tekin, 2013). The existence of job resources (e.g. collaboration with colleagues, the opportunity to use different skills, performance feedback and training) and personal resources (e.g. self-esteem, optimism, feelings of confidence and efficacy) lead to high levels of employee work engagement (Burke et al., 2013). Work engagement increases when the following three psychological states are present (Kahn, 1990; Petchsawang \& McLean, 2017):

1. psychological meaningfulness (the sense of a fruitful outcome of investment of the self in role performance)

2. psychological safety (self-assurance in displaying self without fear or negative repercussions to self-image, status or career)

3. psychological availability (the certainty that a person may embark on a role with the emotional, psychological and physical resources required to perform a task).

Work engagement has been linked strongly with employee retention in the literature (Coetzee et al., 2016; Takawira, Coetzee, \& Schreuder, 2014). Furthermore, improving the work engagement of employees is important for HR managers, as it enhances organisational productivity, increases retention, decreases absenteeism and enhances the well-being of employees (Du Plessis \& Boshoff, 2018). Furthermore, increasing work engagement therefore requires an understanding of related influences from an HRM perspective. A literature review revealed that there is little scientific knowledge on the theoretical and empirical relationship between retention factors and work engagement in the South African public schools context. Hence, there is the need for an empirical study such as the present work to establish the relationship between retention factors and work engagement, and the likely results of using retention factors and work engagement to improve employee retention. The following research question has been formulated in line with the identified gap: is there a significant relationship between retention factors and work engagement of teachers working in Tshwane Municipality public schools?

\section{Hypotheses}

The following three hypotheses were set for this study:

H1: Retention factors positively and significantly correlate with work engagement.

H2: Retention factors positively and significantly predict work engagement.

H3: Retention factors positively and significantly predict the three sub-factors of work engagement, namely, vigour, dedication and absorption.

The next section of the article focusses on the research method, which includes the discussion about the participants and research settings, the measuring instruments, ethical 
considerations, statistical analysis, followed by a presentation of the results. The article then discusses the findings and concludes with the main conclusions, implications for practice and recommendations for potential future research.

\section{Research method \\ Participants and setting}

The study was quantitative (non-experimental) in nature, and a survey was conducted. A convenience sampling technique was used with 708 questionnaires distributed to teachers in Tshwane Municipality public schools. The participants were selected based on their availability and convenience. A total of 303 questionnaires were collected, but 25 questionnaires were excluded from the final analysis, as they were either unfinished or spoilt. The final sample consisted of 278 teachers, resulting in a response rate of $39 \%$.

\section{Measuring instruments}

Döckel's (2003) Retention Factors Measurement Scale (RFMS) was used to measure employees' satisfaction with retention factors. The RFMS contains items that measure employees' satisfaction with compensation, job characteristics, training and development opportunities, supervisor support, career opportunities and work-life policies (Coetzee \& Stoltz, 2015; Döckel, Basson, \& Coetzee, 2006; Shibiti, 2017). The RFMS in this study used a five-point Likert-type scale ranging from (1) 'strongly dissatisfied' to (5) 'strongly satisfied'. The retention factors in the work of Dhanpat, Manakana, Mbacaza, Mokone and Mtongana (2019) had the following acceptable reliability results: compensation (0.97), job content (0.67), training and development (0.92), supervisor support (0.82), career advancement (0.85), work-life balance (0.88), work environment (0.91) and job security (0.79). In the context of this study, the RFMS provided a reliability coefficient of 0.93 , therefore proving itself reliable.

Utrecht Work Engagement Scale (Utrecht Work Engagement Scale [UWES]-17), developed by Schaufeli and Bakker (2004), was used to measure work engagement. The UWES-17 measures employees' level of absorption, dedication and vigour at work (Kulikowski, 2019; Schaufeli \& Bakker 2004; Vallières, McAuliffe, Hyland, Galligan, \& Ghee, 2017). The UWES used a five-point Likert-type scale ranging from (1) 'strongly disagree' to (5) 'strongly agree' (Petchsawang \& McLean, 2017). The UWES-17 was relevant to this study, as the three sub-scales of the instrument have been found to be constant over time and reliable across samples from diverse contexts (Burke et al., 2013; Schaufeli \& Bakker, 2004). The initial reliability of the UWES-17 was found to be 0.93 (Schaufeli \& Bakker, 2004), which is comparable to the reliability of the UWES-17 as found in this study (0.95), thus proving itself reliable in this context.

\section{Research procedure and ethical consideration}

The results presented in this research form part of a Master of Commerce study that was conducted at the University of
South Africa (Unisa) by the author of this article. Permission was attained from the Research, Ethics and Innovation Committee (DREC) of the Department of Human Resource Management, Unisa, and the Department of Basic Education (Gauteng: Department of Education and Tshwane North District). Questionnaires were circulated to teachers together with envelopes and a cover letter. The cover letter provided contact details of the student and the supervisors, and explained the purpose of the study and the ethical standards followed in the study. Prudent measures were implemented to guarantee the anonymity and privacy of participants during the process of collecting, analysing and interpreting the data. Therefore, the findings cannot be linked to the individual participants.

\section{Statistical analysis}

The Statistical Package for Social Sciences (SPSS), Version 23, was used to analyse the data. Pearson's product moment correlations and multiple regression analysis were conducted to determine the correlations between retention factors and work engagement, and to establish whether retention factors (independent) predicted work engagement (dependent). To establish the statistical significance and counter the probability of type 1 errors, the confidence interval level was set at $95 \%$ $(p \leq 0.05)$ and the practical effect size at $r \geq 0.30 \geq 0.50$ (medium to large effect) (Mitonga-Monga \& Cilliers, 2015; Tredoux \& Durrheim, 2013).

\section{Results \\ Descriptive statistics}

This section reports on the means, standard deviations and the reliability of the two instruments that were used in this study. Table 2 provides the means, standard deviations and Cronbach's alpha for the retention factors and work engagement variables. The mean and standard deviation for RFMS were $3.08(M)$ and $0.51(\mathrm{SD})$, respectively. This indicates that the participants were unsure about their satisfaction with retention factors provided by their organisation. The UWES mean and standard deviation were $3.87(M)$ and 0.72 (SD), respectively. This indicates that the participants were moderately engaged in their work. Apart from two sub-items of retention factors, namely, supervisor support $(r=0.50)$ and

TABLE 2: Descriptive statistics for Retention Factors Measurement Scale and Utrecht Work Engagement Scale.

\begin{tabular}{lccc}
\hline Variables & Mean & Standard deviations & Cronbach's alpha \\
\hline RFMS & 3.08 & 0.51 & 0.91 \\
Compensation & 2.95 & 0.91 & 0.97 \\
Job characteristics & 3.15 & 0.53 & 0.48 \\
Training and development & 3.43 & 0.84 & 0.90 \\
Supervisor support & 2.95 & 0.55 & 0.50 \\
Career opportunities & 3.19 & 0.65 & 0.65 \\
Work-life balance & 2.91 & 1.00 & 0.88 \\
UWES & 3.87 & 0.72 & 0.95 \\
Vigour & 3.79 & 0.77 & 0.89 \\
Dedication & 4.03 & 0.81 & 0.90 \\
Absorption & 3.81 & 0.79 & 0.88 \\
\hline
\end{tabular}

RFMS, Retention Factors Measurement Scale; UWES, Utrecht Work Engagement Scale. 
job characteristics $(r=0.48)$, which were below 0.60 , both RFMS and UWES were found to be reliable $(r \geq 0.60)$.

\section{Correlations analysis}

The correlations between retention factors and work engagement were calculated by computing the Pearson's product moment correlations. To determine the statistical significance, the confidence interval level was set at 95\% ( $p \leq 0.05)$ and the cut-off practical effect size was $r \geq 0.30$ $\geq 0.50$ (medium to large effect) (Tredoux \& Durrheim, 2013). Table 3 illustrates the Pearson product moment correlations between RFMS and UWES.

Table 3 demonstrates that RFMS significantly and positively correlates with UWES ( $r=0.60$; large effect; $p \leq 0.001$ ). The results also indicated that, overall, RFMS correlated significantly with vigour $(r=0.60$; large effect; $p \leq 0.001)$, dedication ( $r=0.54$; large effect; $p \leq 0.01)$ and absorption $(r=0.49$; medium effect; $p \leq 0.01)$, as given in the top row of Table 3. Therefore, Hypothesis 1 is accepted.

\section{Multiple regressions analysis}

Table 4 illustrates the results of the multiple regression analyses that were conducted to establish whether retention factors positively and significantly predict work engagement. For multiple regressions to take place, multicollinearity needs to be evaluated. Multicollinearity refers to the relationship between two or more independent variables, and it happens when the independent variables are highly correlated $(r>$ 0.90) (Mitonga-Monga, 2015). The present study made use of tolerance and variance inflation factor (VIF) to test for the assumptions of multicollinearity. Tolerance values that are less than 0.10 and VIF above 10 suggest that there is a possible multicollinearity problem (Hair, Black, Babin, \& Anderson, 2010). No concerns of multicollinearity were detected in the tests as shown in Tables 4-7.

The regression models were generated and were found to be statistically significant $(F p<0.05)$, as highlighted in the subsequent sections. The model contributed $40 \%\left(R^{2}=0.40\right.$ :

work engagement) of the variance in the work engagement variable. In Model 1 (UWES), compensation $(\beta=0.32 ; p=0.001$ ), training and development $(\beta=0.28 ; p=0.001)$, and career opportunities $(\beta=0.19 ; p=0.01)$ acted as significant positive predictors of overall work engagement, with compensation, training and development, and career opportunities contributing the most towards explaining the variance in overall work engagement. Therefore, Hypothesis 2 is accepted.

Model 2 (vigour) in Table 5 revealed that compensation $(\beta=0.35 ; p=0.001)$, training and development $(\beta=0.26$; $p=0.001)$ and career opportunities $(\beta=0.16 ; p=0.01)$ act as significant positive predictors of vigour, with compensation, career opportunities, and training and development, contributing the most to explaining the variance in vigour.

Model 3 (dedication) in Table 6 shows that compensation $(\beta=0.26 ; p=0.001)$, training and development $(\beta=0.31$; $p=0.001)$ and career opportunities $(\beta=0.15 ; p=0.05)$ acted as significant positive predictors of dedication, with training and development, compensation and career opportunities, contributing the most in explaining the variance in dedication.

TABLE 4: Multiple regression analysis: Retention Factors Measurement Scale as a predictor of Utrecht Work Engagement Scale $(N=278)$.

\begin{tabular}{|c|c|c|c|c|c|c|c|c|}
\hline \multirow[t]{2}{*}{ Variable } & \multicolumn{8}{|c|}{ Model 1: UWES } \\
\hline & $B$ & $\beta$ & $p$ & Tolerance & VIF & $d f$ & $\begin{array}{l}\text { Mean } \\
\text { square }\end{array}$ & Value \\
\hline Constant & 29.34 & - & - & - & - & - & - & - \\
\hline Compensation & 0.33 & $0.32 * * *$ & 0.00 & 0.721 & 1.386 & - & - & - \\
\hline Job characteristics & 0.03 & 0.01 & 0.93 & 0.695 & 1.439 & - & - & - \\
\hline Training and development & t 0.67 & $0.28 * * *$ & 0.00 & 0.565 & 1.769 & - & - & - \\
\hline Supervisor support & -0.10 & -0.03 & 0.59 & 0.753 & 1.327 & - & - & - \\
\hline Career opportunities & 0.61 & $0.19 * *$ & 0.01 & 0.603 & 1.657 & - & - & - \\
\hline Work or life balance & -0.02 & -0.01 & 0.91 & 0.915 & 1.093 & - & - & - \\
\hline$F$ & - & - & - & - & - & 62 & 2782.54 & $31.07 * * *$ \\
\hline$R$ & - & - & - & - & - & - & - & 0.64 \\
\hline$R^{2}$ & - & - & - & - & - & - & - & 0.41 \\
\hline Adjusted $R^{2}$ & - & - & - & - & - & - & - & $0.40 \S$ \\
\hline $\begin{array}{l}\text { Standard error of the } \\
\text { estimate }\end{array}$ & - & - & - & - & - & - & - & 9.46 \\
\hline \multicolumn{9}{|c|}{$\begin{array}{l}\beta \text {, standardised regression coefficient; } B \text {, unstandardised regression coefficient; UWES, } \\
\text { Utrecht Work Engagement Scale; VIF, variance inflation factor; } \mathrm{df} \text {, degrees of freedom. }\end{array}$} \\
\hline \multicolumn{9}{|c|}{$\begin{array}{l}\dagger, R^{2} \leq 0.12 \text { (small practical effect size); } \downarrow, R^{2} \geq 0.13 \leq 0.25 \text { (medium practical effect size) } \\
\S, R^{2} \geq 0.26 \text { (large practical effect size). }\end{array}$} \\
\hline \multicolumn{9}{|l|}{$* *, p \leq 0.01 ; * * *, p \leq 0.001$} \\
\hline
\end{tabular}

TABLE 3: Correlations between the Retention Factors Measurement Scale and Utrecht Work Engagement Scale $(N=278)$

\begin{tabular}{|c|c|c|c|c|c|c|c|c|c|c|c|}
\hline Variables & RFMS & Compensation & $\begin{array}{c}\text { Job } \\
\text { characteristics }\end{array}$ & $\begin{array}{l}\text { Training and } \\
\text { development }\end{array}$ & $\begin{array}{l}\text { Supervisor } \\
\text { support }\end{array}$ & $\begin{array}{c}\text { Career } \\
\text { opportunities }\end{array}$ & $\begin{array}{c}\text { Work/life } \\
\text { balance }\end{array}$ & UWES & Vigour & Dedication & Absorption \\
\hline RFMS & 1 & $0.84^{* * *}$ & $0.50^{* * *}$ & $0.74 * * *$ & $0.38^{* *}$ & $0.68^{* * *}$ & $0.17^{*}$ & $0.60^{* * *}$ & $0.60^{* * *}$ & $0.54^{* * *}$ & $0.49 * *$ \\
\hline Compensation & - & 1 & $0.26^{*}$ & $0.51 * * *$ & 0.08 & $0.37 * *$ & -0.09 & $0.53 * * *$ & $0.55^{* * *}$ & $0.47 * *$ & $0.42 * *$ \\
\hline Job characteristics & - & - & 1 & $0.34^{* *}$ & $0.43 * *$ & $0.42 * *$ & 0.03 & $0.25 *$ & $0.25 *$ & $0.22 *$ & $0.22 *$ \\
\hline Training and development & - & - & - & 1 & $0.13^{*}$ & $0.55^{* * *}$ & $-0.10^{*}$ & $0.55^{* * *}$ & $0.54 * * *$ & $0.52 * * *$ & $0.43 * *$ \\
\hline Supervisor support & - & - & - & - & 1 & $0.28^{*}$ & $0.24 *$ & 0.09 & 0.07 & $0.10^{*}$ & 0.08 \\
\hline Career opportunities & - & - & - & - & - & 1 & 0.06 & $0.46^{* *}$ & $0.43^{* *}$ & $0.41^{* *}$ & $0.40 * *$ \\
\hline Work or life balance & - & - & - & - & - & - & 1 & -0.06 & -0.07 & -0.07 & -0.02 \\
\hline UWES & - & - & - & - & - & - & - & 1 & $0.90 * * *$ & $0.92 * * *$ & $0.90 * * *$ \\
\hline Vigour & - & - & - & - & - & - & - & - & 1 & $0.77 * * *$ & $0.67 * * *$ \\
\hline Dedication & - & - & - & - & - & - & - & - & - & 1 & $0.76 * * *$ \\
\hline Absorption & - & - & - & - & - & - & - & - & - & - & 1 \\
\hline
\end{tabular}

$r \geq 0.29$ (small effect); $r \geq 0.30 \geq r \leq 0.49$ (medium effect); $r \geq 0.50$ (large effect).

RFMS, Retention Factors Measurement Scale; UWES, Utrecht Work Engagement Scale.

${ }^{*}, p \leq 0.05 ;{ }^{* *}, p \leq 0.01 ; * * *, p \leq 0.001$. 
TABLE 5: Multiple regression analysis: Retention Factors Measurement Scale as a predictor of vigour $(N=278)$.

\begin{tabular}{|c|c|c|c|c|c|c|c|c|}
\hline \multirow[t]{2}{*}{ Variable } & \multicolumn{8}{|c|}{ Model 2: Vigour } \\
\hline & $\boldsymbol{B}$ & $\beta$ & $p$ & Tolerance & VIF & $d f$ & $\begin{array}{l}\text { Mean } \\
\text { square }\end{array}$ & Value \\
\hline Constant & 9.44 & & & & & - & - & - \\
\hline Compensation & 0.14 & $0.35 * * *$ & 0.00 & 0.721 & 1.386 & - & - & - \\
\hline Job characteristics & 0.04 & 0.020 & 0.73 & 0.695 & 1.439 & - & - & - \\
\hline Training and development & 0.24 & $0.26 * * *$ & 0.00 & 0.565 & 1.769 & - & - & - \\
\hline Supervisor support & -0.07 & -0.05 & 0.35 & 0.753 & 1.327 & - & - & - \\
\hline Career opportunities & 0.19 & $0.16^{* *}$ & 0.01 & 0.603 & 1.657 & - & - & - \\
\hline Work or life balance & -0.01 & -0.01 & 0.81 & 0.915 & 1.093 & - & - & - \\
\hline$F$ & - & - & - & - & - & 6 & 403.72 & $31.07 * * *$ \\
\hline$R$ & - & - & - & - & - & - & - & 0.64 \\
\hline$R^{2}$ & - & - & - & - & - & - & - & 0.41 \\
\hline Adjusted $R^{2}$ & - & - & - & - & - & - & - & $0.40 \S$ \\
\hline $\begin{array}{l}\text { Standard error of the } \\
\text { estimate }\end{array}$ & - & - & - & - & - & - & - & 3.61 \\
\hline \multicolumn{9}{|c|}{$\begin{array}{l}\beta \text {, standardised regression coefficient; } B \text {, unstandardised regression coefficient; VIF, variance } \\
\text { inflation factor; df, degrees of freedom. }\end{array}$} \\
\hline \multicolumn{9}{|c|}{$\begin{array}{l}\dagger, R^{2} \leq 0.12 \text { (small practical effect size); } \$, R^{2} \geq 0.13 \leq 0.25 \text { (medium practical effect size) } \\
\S, R^{2} \geq 0.26 \text { (large practical effect size). }\end{array}$} \\
\hline \multicolumn{9}{|c|}{$*, p \leq 0.05 ; * *, p \leq 0.01 ; * * *, p \leq 0.001$. } \\
\hline
\end{tabular}

TABLE 6: Multiple regression analysis: Retention Factors Measurement Scale as a predictor of dedication $(N=278)$.

\begin{tabular}{|c|c|c|c|c|c|c|c|c|}
\hline \multirow[t]{2}{*}{ Variable } & \multicolumn{8}{|c|}{ Model 3: Dedication } \\
\hline & $B$ & $\beta$ & $p$ & Tolerance & VIF & $d f$ & $\begin{array}{l}\text { Mean } \\
\text { square }\end{array}$ & Value \\
\hline Constant & 9.17 & & & & & - & - & - \\
\hline Compensation & 0.09 & $0.26 * * *$ & 0.00 & 0.721 & 1.386 & - & - & - \\
\hline Job characteristics & -0.05 & -0.023 & 0.69 & 0.695 & 1.439 & - & - & - \\
\hline Training and development & 0.25 & $0.31 * * *$ & 0.00 & 0.565 & 1.769 & - & - & - \\
\hline Supervisor support & 0.01 & 0.01 & 0.85 & 0.753 & 1.327 & - & - & - \\
\hline Career opportunities & 0.16 & $0.15^{*}$ & 0.02 & 0.603 & 1.657 & - & - & - \\
\hline Work or life balance & -0.02 & -0.02 & 0.68 & 0.915 & 1.093 & - & - & - \\
\hline$F$ & - & - & - & - & - & 6 & 263.08 & $23.71 * * *$ \\
\hline$R$ & - & - & - & - & - & - & - & 0.59 \\
\hline$R 2$ & - & - & - & - & - & - & - & 0.25 \\
\hline Adjusted $R^{2}$ & - & - & - & - & - & - & - & $0.33 \S$ \\
\hline $\begin{array}{l}\text { Standard error of the } \\
\text { estimate }\end{array}$ & - & - & - & - & - & - & - & 3.33 \\
\hline \multicolumn{9}{|c|}{$\begin{array}{l}\text { standardised regression coefficient; } B \text {, unstandardised regression coefficient; VIF, variance } \\
\text { inflation factor; df, degrees of freedom. }\end{array}$} \\
\hline$\dagger, R^{2} \leq 0.12$ (small practical & al effect & t size); $\ddagger$ & $R^{2} \geq 0$ & $.13 \leq 0.25$ & (mediur & & oractical & \\
\hline
\end{tabular}

Model 4 (absorption) in Table 7 shows that compensation $(\beta=0.25 ; p=0.001)$, training and development $(\beta=0.19$; $p=0.01)$ and career opportunities $(\beta=0.21 ; p=0.01)$ acted as significant positive predictors of absorption, with compensation, training and development, and career opportunities, contributing the most to explaining the variance in absorption.

Models 2-4 in Tables 5-7 show the results for the multiple regression analyses that were conducted to establish whether retention factors positively and significantly predict vigour, dedication and absorption, respectively. Three additional regression models were generated, and all of them were found to be statistically significant $(F p \leq 0.05)$. The models contributed $40 \%\left(R^{2}=0.40\right.$ : vigour $), 33 \%\left(R^{2}=0.33\right.$ : dedication $)$ and $25 \%\left(R^{2}=0.25\right.$ : absorption $)$ of the variance in the variables of these three sub-factors of work engagement. Therefore, Hypothesis 3 is accepted.
TABLE 7: Multiple regression analysis: Retention Factors Measurement Scale as a predictor of absorption $(N=278)$.

\begin{tabular}{|c|c|c|c|c|c|c|c|c|}
\hline \multirow{2}{*}{ Variable } & \multicolumn{8}{|c|}{ Model 4: Absorption } \\
\hline & $B$ & $\beta$ & $p$ & Tolerance & VIF & $d f$ & $\begin{array}{l}\text { Mean } \\
\text { square }\end{array}$ & Value \\
\hline Constant & 10.73 & & & & & - & - & - \\
\hline Compensation & 0.10 & $0.25 * * *$ & 0.00 & 0.721 & 1.386 & $6-$ & - & - \\
\hline Job characteristics & 0.03 & 0.01 & 0.83 & 0.695 & 1.439 & 9 - & - & - \\
\hline Training and development & 0.18 & $0.19 * *$ & 0.01 & 0.565 & 1.769 & $9-$ & - & - \\
\hline Supervisor support & -0.05 & -0.03 & 0.57 & 0.753 & 1.327 & 7 - & - & - \\
\hline Career opportunities & 0.25 & $0.21 * *$ & 0.00 & 0.603 & 1.657 & 7 - & - & - \\
\hline Work or life balance & 0.02 & 0.02 & 0.76 & .915 & 1.093 & $3-$ & - & - \\
\hline$F$ & - & - & - & - & - & 6 & 277.19 & $16.66 * * *$ \\
\hline$R$ & - & - & - & - & - & - & - & 0.52 \\
\hline$R^{2}$ & - & - & - & - & - & - & - & 0.27 \\
\hline Adjusted $R^{2}$ & - & - & - & - & - & - & - & $0.25 \S$ \\
\hline $\begin{array}{l}\text { Standard error of the } \\
\text { estimate }\end{array}$ & - & - & - & - & - & - & - & 4.08 \\
\hline \multicolumn{9}{|l|}{ VIF, variance inflation factor. } \\
\hline \multicolumn{9}{|c|}{$\begin{array}{l}\beta \text {, standardised regression coefficient; } B \text {, unstandardised regression coefficient; VIF, variance } \\
\text { inflation factor; df, degrees of freedom. } \\
\dagger, R^{2} \leq 0.12 \text { (small practical effect size); } \$, R^{2} \geq 0.13 \leq 0.25 \text { (medium practical effect size) } \\
\S, R^{2} \geq 0.26 \text { (large practical effect size). }\end{array}$} \\
\hline
\end{tabular}

\section{Discussion Outline of the results}

The first objective of this study aimed to determine whether retention factors positively and significantly correlate with work engagement. The correlation results revealed that retention factors correlated with work engagement, implying that the participants who were satisfied with the retention factors appeared to have a high level of work engagement. The findings support Presbitero's (2017) assertion that enhancing HRM practices, particularly compensation, training and development, may improve work engagement of employees. In terms of the second objective, three sub-factors of retention factors, namely, compensation, training and development, and career opportunities correlated with vigour, dedication and absorption. This suggested that the participants who were happy with their opportunities in these three retention factors were more vigorous, dedicated and absorbed in their work. However, this study found no significant correlations between perceived supervisor support and vigour and absorption. The finding differs from those of various authors, which revealed that supervisor support correlates with work engagement (Palo \& Rothmann, 2016; Rothmann \& Fouché, 2018; Schaufeli \& Bakker, 2004). Moreover, no significant correlations were found between the perceived satisfaction with work or life balance arrangement and vigour, dedication and absorption. Nevertheless, other researchers have proposed that organisations could provide employees with flexible working arrangements to develop their vigour and dedication (Coetzee, Schreuder, \& Tladinyane, 2014; Rudolph \& Baltes, 2017).

The second objective aimed to determine whether retention factors positively and significantly predict work engagement. The multiple regression results revealed that retention factors predict work engagement. The third objective aimed to determine 
whether the six sub-factors of retention factors, namely, compensation, job characteristics, training and development opportunities, supervisor support, career opportunities and work or life balance positively and significantly predict the three sub-factors of work engagement, namely, vigour, dedication and absorption. The results revealed that compensation, training and development, and career opportunities contribute more in explaining the difference in employees' level of vigour, dedication and absorption (Shibiti, 2017). This suggests that when employees are satisfied with their compensation, training and development, and career opportunities in their organisation, they are more likely to display high levels of work engagement. The findings support Mendes and Stander's (2011) contention that employees are prone to display positive affective responses, such as emotional energy, physical strength and cognitive liveliness, when their work is meaningful, when they receive regular developmental opportunities and when they are provided with clear performance objectives.

\section{Limitations of the study}

The following limitations of the empirical study should be considered when interpreting the findings:

- The study was restricted to 278 teachers working in Tshwane Municipality public schools. Convenience sampling was used to choose the participants. Therefore, it is not possible to generalise the results of this study to all populations and different work environments. If the findings are to be representative of the total workforce, quantitative studies similar to this study should be conducted with more participants, bearing in mind the large number of teachers in public schools.

- The study was cross-sectional in nature, and as a result, it was not possible to draw inferences about the cause and effect relationship between the two variables. Hence, the findings were interpreted rather than established.

- Three sub-factors of retention factors, namely, job characteristics, supervisory supportand careeropportunities produced low reliability scores. The low reliability scores can be attributed to the relatively moderate sample size, as previous research has confirmed the validity and reliability of these items in different contexts.

Nevertheless, the findings of this study provided new knowledge on the relationship between satisfaction with retention factors and work engagement, as it applies to the public school context in South Africa.

\section{Practical implications and recommendations}

The results from this study provide solid implications for employers in need of effective employee retention strategies. The main practical contribution of this work is the way in which it demonstrates that retention factors correlate with and predict work engagement. The findings confirmed the need to consider retention factors in the public school context to understand the work engagement of public school teachers. Organisations should provide their employees with improved compensation, training and development, and career opportunities, as this may improve employees' vigour, absorption and dedication at work. Consequently, organisations should determine whether employees are satisfied with these factors, as provided in the organisation.

\section{Future studies}

This study demonstrated that there is a serious need for further research into the relationship between retention factors and work engagement. It is recommended that future research should apply strategies to mitigate the limitations identified in this study. The study was restricted to 278 teachers working in Tshwane Municipality public schools and, as such, future research should use a randomised sampling process with larger samples and include different occupational fields, races, genders and ages.

This study was cross-sectional in nature, and it was therefore not possible to determine cause and effect relationships between the variables under study. Consequently, longitudinal studies are recommended to determine the influence of satisfaction on retention factors and work engagement in different organisations. Future research should conduct testretest reliability to validate the reliability of the measuring instruments that were used. Different methodologies or combination of methods, both qualitative and quantitative, should be considered, which would result in a broader understanding of the relationship between satisfaction with retention factors and work engagement. Furthermore, demographic information should also be used as moderating variables in an investigation into the relationships between satisfaction with retention factors and work engagement.

\section{Conclusion}

The purposes of this study were to determine the relationship between retention factors and work engagement, and to establish whether retention factors positively and significantly predict work engagement. The empirical statistical relationship that was found between retention factors and work engagement provided new understanding with respect to the retention of employees in an organisation. This study concludes that retention factors play an important role in explaining employees' vigour, absorption and dedication in the workplace. Individuals who are satisfied with compensation, training and development, and career opportunities are more likely to display a high level of work engagement. This strongly suggests that retention factors should be considered in the development of a behavioural model for both retention and performance practices.

\section{Acknowledgements}

The author expresses his heartfelt thanks and sincere appreciation to his MCom supervisor, Dr Jeremy MitongaMonga, and co-supervisor, Ms Mpho Lerotholi. The supervisors 
offered guidance and shared their knowledge and expertise with the author throughout the MCom study. Prof. Ruth de Villiers also provided valuable feedback during the writing retreat organised by the College of Economic and Management Sciences (CEMS). The author also thanks the Department of Basic Education (Gauteng Provincial Department and Tshwane North District), and school principals and teachers for their invaluable input and time.

\section{Competing interests}

The author declares that there is no financial or personal relationships that may have inappropriately influenced the writing of this article.

\section{Authors' contributions}

I declare that I am the sole author of this research article.

\section{Funding information}

The Directorate of Student Funding and the Graduate Development Fellowship programme at the University of South Africa awarded a bursary to the author to conduct the study.

\section{Data availability statement}

Data sharing is not applicable to this article.

\section{Disclaimer}

The views and opinions expressed in this article are the author's own and not an official position of any affiliated agency of the author.

\section{References}

Bailey, C., Madden, A., Alfes, K., \& Fletcher, L. (2017). The meaning, antecedents and outcomes of employee engagement: A narrative synthesis. International Journal of Management Reviews, 19(1), 31-53.

Burke, R.J., Koyuncu, M., Fiksenbaum, L., \& Tekin, Y. (2013) Antecedents and consequences of work engagement among frontline employees in Turkish hotels. Journal of Transnational Management, 18(3), 191-203. https://doi.org/10.1080/ 15475778.2013.817243

Centre for Development and Enterprise. (2015). Teachers in South Africa: Supply and demand 2013-2025. Executive summary. Johannesburg: Centre for Development and Enterprise.

Citizen. (2018). Education Department dismisses claims of teachers leaving SA. Retrieved from https://citizen.co.za/news/south-africa/2018021/educationdepartment-dismisses-claims-of-teachers-leaving-sa/

Coetzee, M., Oosthuizen, R.M., \& Stoltz, E. (2016). Psychosocial employability attributes as predictors of staff satisfaction with retention factors. South African Journal of Psychology, 46(2), 232-243. https://doi.org/10.1177/008124 6315595971

Coetzee, M., \& Pauw, D. (2013). Staff perception of leader emotional competency as a predictor of satisfaction with retention factors. Journal of Psychology in Africa, 23(2), 177-185. https://doi.org/10.1080/14330237.2013.10820613

Coetzee, M., Schreuder, D., \& Tladinyane, R. (2014). Employees' work engagement and job commitment: The moderating role of career anchors. South African Journal of Human Resource Management, 12(1), 1-12. https://doi.org/10.4102/ sajhrm.v12i1.572

Coetzee, M. \& Stoltz, E. (2015). Employees' satisfaction with retention factors: Exploring the role of career adaptability. Journal of Vocational Behavior 89(August), 83-91. https://doi.org/10.1016/j.jvb.2015.04.012

Cohen, M., Cavazotte, F.C.N., Da Costa, T.M., \& Ferreira, K.C.S. (2017). Corporate social-environmental responsibility as an attraction and retention factor for young professionals. Brazilian Business Review, 14(1), 21-41. https://doi.org/10.15728/ bbr.2017.14.1.2
Davidescu, A.A., \& Issa Eid, T.M. (2017). Identifying the main determinants of retention in Jordanian hospitals. An empirical analysis based on Mccloskey/ Mueller satisfaction scale. Ecoforum, 6(1), 1-9.

Dhanpat, N., Manakana, T., Mbacaza, J., Mokone, D., \& Mtongana, B. (2019). Exploring retention factors and job security of nurses in Gauteng public hospitals in South Africa. African Journal of Economic and Management Studies, 10(1), 57-71. https://doi.org/10.1108/AJEMS-10-2018-0311

Dhanpat, N., Modau, F.D., Lugisani, P., Mabojane, R., \& Phiri, M. (2018). Exploring employee retention and intention to leave within a call centre. South African Journal of Human Resource Management, 16(0), a905. https://doi.org/10.4102/ sajhrm.v16i0.905

Döckel, A. (2003). The effect of retention factors on organisational commitment: An investigation of high technology employees. Unpublished master's dissertation. University of Pretoria: Pretoria.

Döckel, A., Basson, J., \& Coetzee, M. (2006). The effect of retention factors on organisational commitment: An investigation of high technology employees. South African Journal of Human Resource Management, 4(2), 20-28. https://doi. org/10.4102/sajhrm.v4i2.91

Du Plessis, M. \& Boshoff, A.B. (2018). Authentic leadership, followership, and psychological capital as antecedents of work engagement. Journal of Psychology in Africa, 28(1), 26-32. https://doi.org/10.1080/14330237.2018.1438832

Fouché, E., Rothmann, S., \& Van der Vyver, C. (2017). Antecedents and outcomes of meaningful work among school teachers. SA Journal of Industrial Psychology, 43(0), a1398. https://doi.org/10.4102/sajip.v43i0.1398

Furuta, S.H. (2015). A case study of teacher retention in three Title I Hawaii schools. Doctoral thesis. Ann Arbor, MI: ProQuest.

Hair, J.F., Black, W.C., Babin, B.J., \& Anderson, R.E. (2010). Multivariate data analysis A global perspective (7th edn.). Upper Sadler Rever, NJ: Pearson.

Hugo, J.P. (2018). The development and implementation of an effective mentoring programme to improve job satisfaction among beginner teachers at primary schools in the Mpumalanga Province of South Africa. Unpublished doctoral thesis. Pretoria: University of South Africa. Retrieved from http://hdl.handle.net/10500/24842

Kahn, W. (1990). Psychological conditions of personal engagement and dis-engagement at work. The Academy of Management Journal, 33, 692-724. https://doi. org/10.2307/256287

Kallioniemi, M.K., Kaseva, J., Kolstrup, C.L., Simola, A., \& Kymäläinen, H. (2018). Job resources and work engagement among Finnish dairy farmers. Journal of Agromedicine, 23(3), 249-261. https://doi.org/10.1080/1059924X.2018.1470047

Kulikowski, K. (2019). One, two or three dimensions of work engagement? Testing the factorial validity of the Utrecht Work Engagement Scale on a sample of Polish employees. International Journal of Occupational Safety and Ergonomics, 25(2) 241-249. https://doi.org/10.1080/10803548.2017.1371958

Kumar, G.S., \& Santhosh, C. (2014). Factor analysis approach to explore dimensions of employee retention in BPO industry in Kerala. Journal of Social Welfare and Management, 6(2), 69-78.

Lyria, R.K., Namusonge, G.S., \& Karanja, K. (2017). The effect of talent retention on organizational performance of firms listed in the Nairobi Securities Exchange. Journal of Human Resource and Leadership, 1(3), 56-68.

Mafukata, A M., \& Mudau, A.V. (2016). Exploring teacher mass resignation and early retirement from public schools. Dirasat: Human and Social Sciences, 43(5), 2243-2255.

Mahalakshmi, R., \& Rao, B.N. (2012). A study on effective employee retention strategies. International Journal of Logistics \& Supply Chain Management Perspectives, 1(1), 18-21.

Malik, O.F., Shahzad, A., \& Raziq, M.M. (2019). Work engagement in the face of terrorism: The moderating role of trait resilience. Journal of Aggression, Maltreatment \& Trauma, 1-18. https://doi.org/10.1080/10926771.2019.1581863

Mampane, P. (2012). The teacher turnover crisis: Evidence from South Africa. Business Education \& Accreditation, 4(2), 73-83. Retrieved from https://ssrn.com/ abstract $=2144991$

Mendes, F., \& Stander, M.W. (2011). Positive organisation: The role of leader behaviour in work engagement and retention. South African Journal of Industrial Psychology, 37(1), 1-13. https://doi.org/10.4102/sajip.v37i1.900

Mitonga-Monga, J. (2015). The effects of ethical context and behaviour on job retention and performance-related factors. Unpublished doctoral thesis. Pretoria: University of South Africa.

Mitonga-Monga, J., \& Cilliers, F. (2015). Ethics culture and ethics climate in relation to employee engagement in a developing country setting. Journal of Psychology in Africa, 25(3), 242-249. https://doi.org/10.1080/14330237.2015.1065059

Mitonga-Monga, J., \& Hlongwane, V. (2017). Effects of employees' sense of coherence on leadership style and work engagement. Journal of Psychology in Africa, 27(4), 351-355. https://doi.org/10.1080/14330237.2017.1347757

Miya, N. (2017). Why teachers are leaving their profession. Retrieved from https:// www.news 24 .com/SouthAfrica/News/why-teachers-are-leaving-theirprofession-20170830

Mohammad, A. (2015). Employee recruitment, selection and retention in Saudi Arabian family owned small and medium scale enterprises (SMEs). Kuwait Chapter of Arabian Journal of Business and Management Review, 4(6), 30-45. https://doi.org/10.12816/0018967

Nishi, D., Suzuki, Y., Nishida, J., Mishima, K., \& Yamanouchi, Y. (2017). Personal lifestyle as a resource for work engagement. Journal of Occupational Health, 59(1), 17-23. https://doi.org/10.1539/joh.16-0167-OA 
Palo, J., \& Rothmann, S. (2016). Work engagement in the mining industry in South Africa: The role of tasks and relationships. Journal of Psychology in Africa, 26(3), 221-229. https://doi.org/10.1080/14330237.2016.1185901

Pek-Greer, P., \& Wallace, M. (2017). A study of childcare teacher retention in the childcare service industry. Global Business Review, 18(1), 1-16. https://doi. org/10.1177/0972150916666879

Petchsawang, P., \& McLean, G.N. (2017). Workplace spirituality, mindfulness meditation, and work engagement. Journal of Management, Spirituality \& Religion, 14(3), 216244. https://doi.org/10.1080/14766086.2017.1291360

Pitsoe, V.J. (2013). Teacher attrition in South Africa: Trends, challenges and prospects Journal of Social Sciences, 36(3), 309-318. https://doi.org/10.1080/09718923.20 13.11893197

Presbitero, A. (2017). How do changes in human resource management practices influence employee engagement? A longitudinal study in a hotel chain in the Philippines. Journal of Human Resources in Hospitality and Tourism, 16(1), 56-70. https://doi.org/10.1080/15332845.2016.1202061

Reitz, O. (2014). Job embeddedness: A concept analysis. Nursing Forum, 49(3), 159166. https://doi.org/10.1111/nuf.12053

Roy, B. (2015). A study on employee retention factors in the Indian banking industry - An empirical study. International Journal of Advanced Research in Computer Science and Management Studies, 3(3), 346-352.

Rothmann, S., \& Fouché, E. (2018). School principal support, and teachers' work engagement and intention to leave: The role of psychological need satisfaction. In M. Coetzee, I. Potgieter, \& N. Ferreira (Eds.), Psychology of Retention (pp. 137-156). Cham, Switzerland: Springer. https://doi.org/10.1007/978-3(pp. 137-156)

Rudolph, C.W., \& Baltes, B.B. (2017). Age and health jointly moderate the influence of flexible work arrangements on work engagement: Evidence from two empirical studies. Journal of Occupational Health Psychology, 22(1), 40-58. https://doi. org/10.1037/a0040147

Sandhya, K., \& Kumar, D.P. (2014). Employee retention: A strategic tool for organisational growth and sustaining competitiveness. Journal of Strategic Human Resource Management, 3(3), 42-45.
Schaufeli, W.B., \& Bakker, A.B. (2004). UWES Utrecht Work Engagement Scale: Preliminary manual [measuring instrument]. Utrecht: Utrecht University, Occupational Health Psychology Unit.

Schaufeli, W.B., Salanova, M., Gonzalez-Roma, V., \& Bakker, A.B. (2002). The measurement of engagement and burnout: A two-sample confirmatory factor analytic approach. Journal of Happiness Studies, 3, 71-92. https://doi.org/10.1023/A:1015630930326

Shibiti, R. (2017). The relationship between retention factors, job embeddedness and work engagement of teachers in Tshwane Municipality public schools. Unpublished master's dissertation. Pretoria: University of South Africa.

Takawira, N., Coetzee, M., \& Schreuder, D. (2014). Job embeddedness, work engagement and turnover intention of staff in a higher education institution: An exploratory study. South African Journal of Human Resource Management, 12(1), a524. https://doi.org/10.4102/sajhrm.v12i1.524

Tourangeau, A.E., Patterson, E., Saari, M., Thomson, H., \& Cranley, L. (2017). Work-related factors influencing home care nurse intent to remain employed. Health Care Management Review, 42(1), 87-97. https://doi.org/10.1097/HMR.0000000000000093

Tredoux, C., \& Durrheim, K. (2013). Numbers, hypotheses, and conclusions (2nd edn.). Cape Town: UCT Press.

Vallières, F., McAuliffe, E., Hylanda, P., Galliganb, M., \& Ghee, A. (2017). Measuring work engagement among community health workers in Sierra Leone: Validating the Utrecht Work Engagement Scale. Journal of Work and Organizational Psychology, 33(1), 41-46. https://doi.org/10.1016/j.rpto.2016.12.001

Van Dyk, J., \& Coetzee, M. (2012). Retention factors in relation to organisational commitment in medical and information technology services. South African Journal of Human Resource Management, 10(2), a433. https://doi.org/10.4102/sajhrm.v10i2.433

Van Dyk, J., Coetzee, M., \& Takawira, N. (2013). Satisfaction with retention factors as predictors of the job embeddedness of medical and information technology services staff. Southern African Business Review, 17(1), 57-75. https://doi. org/10.4102/sajhrm.v10i2.433

Wang, X., Liu, L., Zou, F., Hao, J., \& Wu, H. (2017). Associations of occupational stressors, perceived organizational support, and psychological capital with work engagement among Chinese female nurses. BioMed Research International, 2017 1-11. https://doi.org/10.1155/2017/5284628 